\title{
Growth of White Clover Ecotypes, Cultivars, and Germplasms in the Southeastern USA
}

\author{
G. E. Brink,* G. A. Pederson, M. W. Alison, D. M. Ball, J. H. Bouton, R. C. Rawls, \\ J. A. Stuedemann, and B. C. Venuto
}

\begin{abstract}
Naturalized populations, or ecotypes, of white clover (Trifolium repens L.) are found in many southeastern U.S. pastures, often persisting despite adverse environmental and cultural conditions. Our objective was to compare the growth, morphology, and vegetative persistence of white clover ecotypes (small- to medium-leaf) with selected cultivars (large-leaf) and improved germplasm under grazing in four southeastern states. Seed or stolons of white clover ecotypes were collected primarily from grazed pastures in spring 1994 in Louisiana, Mississippi, Alabama, and Georgia, and increased by intercrossing. Plots of seven ecotype collections, 'Osceola', 'Regal', 'Louisiana S-1', 'Grasslands Huia', 'Grasslands Prestige', Brown Loam Synthetic No. 2 germplasm, and Southern Regional Virus Resistant germplasm were established in October 1995 in each state. Plots were stocked continuously with cattle (Bos taurus) (5-cm stubble) from January 1996 to January 1998. Stolon length and axillary bud viability, and number of stolon apices, rooted nodes, and seedlings were measured every $3 \mathrm{mo}$. Stolon length of the ecotypes usually exceeded that of the cultivars and germplasm at all locations, particularly in the winter and spring. By the end of the experiment, the ecotypes also exhibited greater stolon branching than the cultivars and germplasm (1580 vs. 320 branches $\mathrm{m}^{-2}$ ). Superior vegetative growth of the ecotypes was attributed to a greater proportion of the stolon nodes being both branched and rooted, particularly during the summer. White clover ecotypes represent a valuable source of germplasm to incorporate into breeding programs or to develop directly into more persistent cultivars.
\end{abstract}

$\mathrm{W}$ HITE CLOVER is a vital component of permanent pasture systems in New Zealand and Great Britain, contributing to greater animal performance and reduced reliance on $\mathrm{N}$ fertilizer. In both these countries, pastures are dominated by plants with highly branched stolons and small- to medium-leaf size (Caradus et al., 1989; Davies and Young, 1967) primarily because continuous stocking favors this type of growth habit (Frame and Newbould, 1986). The high stolon density exhibited by these types is also required for improved vegetative persistence under grazing (Woodfield and Caradus, 1994). Where white clover ecotypes are found in pastures in the southeastern USA, plants also tend to have small to intermediate leaves and highly branched stolons (Widdup et al., 1996). Their persistence is due to two

G.E. Brink and G.A. Pederson, USDA-ARS, P.O. Box 5367, Mississippi State, MS 39762; M.W. Alison, Macon Ridge Res. Stn., 212 Macon Ridge Rd., Winnsboro, LA 71295; D.M. Ball, 120 Extension Hall, Auburn University, AL 36849-5633; J.H. Bouton, Crop \& Soil Sciences Dep., Univ. of Georgia, Athens, GA 30602-7272; R.C. Rawls, Upper Coastal Plain Substn., P.O. Box 706, Winfield, AL 35594; J.A. Stuedemann, USDA-ARS, J. Phil Campbell, Sr., Natural Resource Conservation Center, 1420 Exp. Stn. Rd., Watkinsville, GA 30677; B.C. Venuto, Louisiana State University, 215 M.B. Sturgis Hall, Baton Rouge, LA 70803. Mississippi Agric. and For. Exp. Stn. Journal Article no. 9215. Received 18 Dec. 1998. *Corresponding author (GEB1@ ra.msstate.edu).

Published in Crop Sci. 39:1809-1814 (1999). mechanisms, each playing a role in the survival of the plants as local environmental conditions dictate: vegetative propagation by stolons and annual reseeding (Hollowell, 1966). Pederson and Brink (1997) found that seed production of pasture-collected white clover ecotypes greatly exceeded that of commercial cultivars when all entries were grazed before flowering.

Despite the predominance of small-leaf white clover in perennial Southeastern pastures, breeding efforts have produced large-leaf germplasm, such as Brown Loam Synthetic No. 2 (Knight et al., 1988) and Southern Regional Virus Resistant (Gibson et al., 1989), and cultivars, such as Tillman, Regal, and Osceola (Williams, 1987) selected primarily for superior yield and disease resistance, often in clipped plots. However, under continuous cattle stocking in a mixed grass species pasture typical of the southeast USA, Osceola, Louisiana S-1, Brown Loam Synthetic No. 2, and SRVR had similar seasonal trends for stolon growth and stolon axillary bud viability, and failed to persist after 2 to $3 \mathrm{yr}$ (Brink et al., 1998). The lack of persistence in grass pastures is considered the primary weakness of white clover (Gibson and Cope, 1985), and producers often cite persistence as more important than productivity when contemplating establishment of a forage crop (D.M. Ball, 1998, personal communication).

A detailed evaluation of white clover ecotypes found in Southeastern pastures and comparison with commercially available cultivars are needed to understand their mechanisms of vegetative persistence and their potential value to breeding programs. The potentially high genetic variation in ecotypes dictates that such an evaluation be conducted at several sites across the region. Our objective was to compare the growth- and persistencerelated morphological traits of regional white clover ecotypes with selected cultivars and improved germplasm under continuous stocking.

\section{MATERIALS AND METHODS}

In 1994, seed or stolons of white clover ecotypes were collected from grazed pastures and farm sites in May, June, and July in Louisiana, Mississippi, Alabama, and Georgia. Pastures from which ecotypes were collected generally had been closely grazed $(<5-\mathrm{cm}$ stubble height) and had contained white clover of unknown origin for $10 \mathrm{yr}$ or more. Associated forage grasses included bahiagrass (Paspalum notatum Flugge), bermudagrass [Cynodon dactylon (L.) Pers.], dallisgrass (Paspalum dilatatum Poir.), or crabgrass [Digitaria sanguinalis (L.) Scop.]. Each collection represented ecotypes from one or more sites within a state or county (Table 1). Ecotypes from different regions within a state were maintained as separate collections

Abbreviations: AL, Alabama ecotype; GA-N, Georgia-north ecotype LA, Louisiana ecotype; LSD, least significant difference; MS-C, Mississippi-central ecotype; SRVR, Southern Regional Virus Resistant. 
Table 1. Sites at which white clover ecotypes were collected.

\begin{tabular}{|c|c|c|c|}
\hline $\begin{array}{l}\text { State } \\
\text { and region }\end{array}$ & $\begin{array}{c}\text { Collection } \\
\text { abbreviation }\end{array}$ & $\begin{array}{c}\text { County } \\
\text { (no. of sites) }\end{array}$ & Collector(s) \\
\hline $\begin{array}{l}\text { Louisiana } \\
\text { Mississippi- }\end{array}$ & LA & Claiborne (2) & Venuto \\
\hline North & MS-N & Pontotoc (4) & Brink \\
\hline $\begin{array}{c}\text { Mississippi- } \\
\text { Central } \\
\text { Mississippi- }\end{array}$ & MS-C & Oktibbeha (5) & $\begin{array}{l}\text { Brink, } \\
\quad \text { Pederson }\end{array}$ \\
\hline $\begin{array}{c}\text { South } \\
\text { Alabama }\end{array}$ & $\begin{array}{l}\text { MS-S } \\
\text { AL }\end{array}$ & $\begin{array}{l}\text { Hinds (3) } \\
\text { Mobile, Clarke, Lamar, } \\
\text { Marion, Limestone, } \\
\text { Dekalb, Calhoun, } \\
\text { Talladega, Chambers, } \\
\text { Montgomery (1 each) }\end{array}$ & $\begin{array}{l}\text { Pederson } \\
\text { Ball }\end{array}$ \\
\hline $\begin{array}{r}\text { Georgia- } \\
\text { North }\end{array}$ & GA-N & Putnam (2) & Bouton \\
\hline $\begin{array}{l}\text { Georgia- } \\
\text { South }\end{array}$ & GA-S & Tift (1) & Bouton \\
\hline
\end{tabular}

if the collector felt there were important factors contributing to potential differences between regions (soil type, climate, associated grasses). With the exception of the Georgia-north (GA-N) collection, where stolon cuttings from the two sites were used to produce seed in an isolated polycross block, mature seedheads from randomly selected plants were collected from each site, dried on a greenhouse bench in a paper bag, and then hand-threshed to remove the seed. Seed from each of the seven collections was increased by intercrossing at least 100 mature plants, with each site within a collection represented by an equal number of plants, in separate cages using honeybees (Aphis mellifera L.). Seed from all plants within a collection was bulked and used to produce field transplants.

In early October 1995, 25 8-wk-old seedlings of each of the seven collections, the cultivars Osceola (large-leaf), Regal (large-leaf), Louisiana S-1 (medium-leaf), Grasslands Huia (medium-leaf), and Grasslands Prestige (small-medium-leaf; Caradus and Woodfield, 1997), and Brown Loam Synthetic No. 2 (large-leaf), and Southern Regional Virus Resistant (large-leaf) germplasm were planted in $1.0-\mathrm{m}^{2}$ plots $(5$ by 5 grid on 20 -cm centers) in bermudagrass sod at each of four locations. A $1.5-\mathrm{m}$ grass alley separated plots. The experimental design was a randomized complete block design with four replicates. Plots were established at the Macon Ridge Research Station, Winnsboro, LA $\left(32^{\circ} 25^{\prime} \mathrm{N}, 91^{\circ} 70^{\prime} \mathrm{W}\right)$ on a Gigger silt loam (fine-silty, mixed thermic Typic Fragiudalf); the Leveck Animal Research Center, Mississippi State, MS $\left(33^{\circ} 45^{\prime} \mathrm{N}, 88^{\circ} 75^{\prime} \mathrm{W}\right)$ on a Savannah fine sandy loam (fineloamy, siliceous, semiactive, thermic Typic Fragiudult); the Alabama Upper Coastal Plain Substation, Winfield, AL $\left(33^{\circ}\right.$ $90^{\prime} \mathrm{N}, 87^{\circ} 85^{\prime} \mathrm{W}$ ) on a Greenville loam (fine, kaolinitic, thermic Rhodic Kandiudult); and at the J. Phil Campbell, Sr., Natural Resource Conservation Center, Watkinsville, GA (33 $85^{\prime} \mathrm{N}$, $83^{\circ} 45^{\prime} \mathrm{W}$ ) on a Cecil sandy loam (fine, kaolinitic, thermic, Typic Kanhapludult). Soils at each location were amended with surface fertilizer application at the beginning of the experiment to attain $75 \mathrm{~kg}$ extractable $\mathrm{P} \mathrm{ha}^{-1}$ (Bray and Kurtz P1), $200 \mathrm{~kg}$ exchangeable $\mathrm{K} \mathrm{ha}^{-1}$, and a $\mathrm{pH}$ of 6.2 to 6.6 in the top $16 \mathrm{~cm}$ of the soil profile.

Beginning in January 1996, plots were continuously stocked (Forage and Grazing Terminology Committee, 1992) with cattle to maintain a sward height of $\approx 5 \mathrm{~cm}$. From April 1996 to January 1998, the following measurements were made every 3 mo on plants within an $80-\mathrm{cm}^{2}$ circular core sampled randomly within each plot: stolon length, number of stolon apices ( $5 \mathrm{~mm}$ or longer), stolon axillary bud viability, number of rooted stolon nodes, and number of seedlings. The viability of axillary buds, or the potential of shoot and root buds to grow at stolon nodes, was evaluated by a modified technique of Newton and Hay (1992). All stolon nodes having $2 \mathrm{~mm}$ of internode proximal and distal to the subject node, with or without a subtending leaf, were excised from the stolon. Nodes having a stolon branch $5 \mathrm{~mm}$ or longer at the time of sampling were considered elongated and were not included in further evaluation. After excision, stolon nodes were placed on moistened 1-mm-thick germination paper in 10 -cm-diameter petri dishes. Petri dishes were sealed with Parafilm-M laboratory film (American Can Co., Greenwich, CT), except for a slit to reduce condensation, and placed in a growth chamber. The chamber was maintained at $20^{\circ} \mathrm{C}$ with a 24 -h photoperiod and photosynthetic photon flux density of $800 \mu \mathrm{mol} \mathrm{m}{ }^{-2} \mathrm{~s}^{-1}$. After $21 \mathrm{~d}$, nodes that had produced a shoot and root (were theoretically capable of producing a stolon branch), were considered viable, and those that did not were considered nonviable (dead, dormant, or reproductive) for that sampling. The proportion of stolon nodes having elongated, viable, and nonviable buds was calculated as the number of nodes assigned to each class divided by the total number of nodes.

Stolon trait means of white clover ecotype collections, cultivars, and germplasms were separated at each sampling date with Fisher's protected LSD $(P \leq 0.05)$. Because entry $\times$ location interactions for all variables were not significant $(P \leq$ $0.05)$ at each of the sampling dates, data were analyzed across locations.

\section{RESULTS AND DISCUSSION}

When the growth of all 14 white clover entries in this experiment was compared, the ecotypes tended to behave as a group on individual sample dates, particularly collections from the same state. Likewise, cultivars and germplasms tended to behave similarly. Presentation and discussion of the results are simplified by presenting results for the cultivars Osceola, Louisiana S-1, and Grasslands Prestige, the germplasm SRVR, and the ecotypes Louisiana (LA), Alabama (AL), Mississippicentral (MS-C), and GA-N (Table 1).

Plants within each collection were grown to maturity from pasture-collected seed in the greenhouse in order to increase seed quantities. All these plants were smallto medium-leaf. Widdup et al. (1996) made similar observations about ecotypes collected in Pennsylvania, Virginia, North Carolina, Georgia, and Mississippi. They found that although the majority of cultivars sold in the United States are large-leaf, only 10 of the 98 ecotype populations they collected had traits characteristic of large-leaf plants. During field evaluation of the cultivars, germplasms, and ecotypes, differences in leaf size among the entries were less apparent, probably because leaves of the large-leaf cultivars were consumed by cattle before reaching maximum size.

When plots were first sampled in April 1996, stolon length of the ecotypes at all four locations exceeded that of the other entries except Grasslands Prestige (Fig. 1). Stolon length declined throughout the summer, reaching minimum values in October, until few differences in stolon length existed among the eight entries. This annual decline in white clover growth (Brink et al., 1998), which occurs in the fall in much of the Southeast because of high summer temperatures, declining precipitation, and a virus disease-insect pest complex (Peder- 


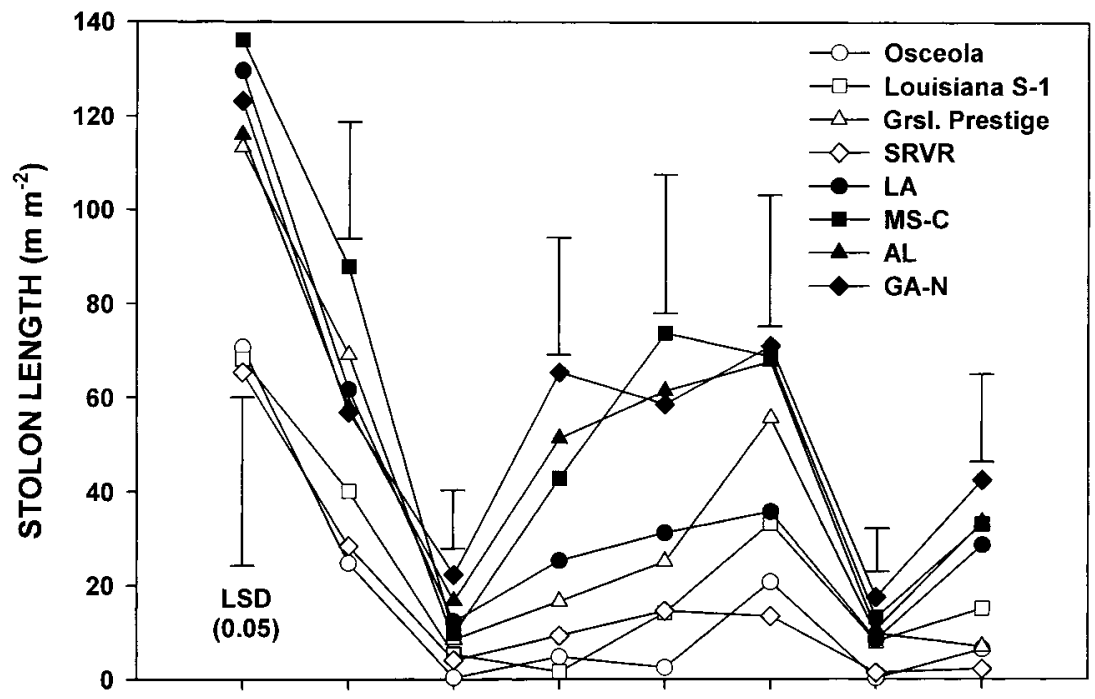

APR 96 JUL 96 OCT 96 JAN 97 APR 97 JUL 97 OCT 97 JAN 98

Fig. 1. Stolon length of three white clover cultivars, one germplasm, and four ecotypes stocked continuously with cattle (mean of four locations).

son et al., 1991), was exhibited by all entries to the same relative degree regardless of previous growth. After October 1996, stolon growth rates of GA-N, AL, and MS resulted in these ecotypes having greater stolon length in January, April, and July 1997 than all cultivars and germplasms except Grasslands Prestige. The growth of Grasslands Prestige during the summer (July 1997) can be attributed to its origin and agronomic performance in New Zealand. It is a small- to medium-leaf type that is suited to close grazing, yields well on dry, warm sites, and has the greatest stolon density of any New Zealand white clover cultivar (Caradus and Woodfield, 1997). The decline in stolon length from July to October in 1996 was repeated in 1997, and like the previous year, few differences were apparent among the entries. After
October, stolon length of the ecotypes again increased more rapidly than that of the cultivars and SRVR, and by January 1998, exceeded that of all other entries except Louisiana S-1 (Fig. 1). Among the ecotypes, the GA-N collection had superior growth relative to the cultivars and SRVR at the greatest number of sampling dates during the experiment.

Although white clover ecotypes were collected across a wide geographical area, there was no tendency for ecotypes to perform better in the state where they were collected than ecotypes collected from other states. The lack of an entry $\times$ location interaction was attributed to the fact that site conditions (weather and soil) influenced clover growth more than genotype. Differences in clover growth among the four sites are best described

Table 2. Mean monthly precipitation and departure from normal (30 yr, 1961-1990) at each experimental location.

\begin{tabular}{|c|c|c|c|c|c|c|c|c|c|}
\hline \multirow[b]{2}{*}{ Year } & \multirow[b]{2}{*}{ Month } & \multicolumn{2}{|c|}{ Winnsboro, LA } & \multicolumn{2}{|c|}{ Mississippi State, MS } & \multicolumn{2}{|c|}{ Winfield, AL } & \multicolumn{2}{|c|}{ Watkinsville, GA } \\
\hline & & Total & Departure & Total & Departure & Total & Departure & Total & Departure \\
\hline \multirow[t]{12}{*}{1996} & January & 151 & 17 & 97 & -40 & 219 & 66 & 188 & 69 \\
\hline & February & 25 & -101 & 38 & -83 & 63 & -79 & 86 & -28 \\
\hline & March & 55 & -93 & 131 & -23 & 121 & -43 & 196 & 57 \\
\hline & April & 233 & 120 & 116 & -29 & 163 & 29 & 96 & -9 \\
\hline & May & 142 & 10 & 13 & -113 & 48 & -58 & 66 & -40 \\
\hline & June & 69 & $-\mathbf{3 1}$ & 97 & 0 & 98 & 8 & 79 & -23 \\
\hline & July & 63 & -34 & 154 & 35 & 264 & 137 & 96 & $-\mathbf{3 0}$ \\
\hline & August & 109 & 21 & 76 & -20 & 99 & 12 & 144 & 47 \\
\hline & September & 64 & -15 & 82 & -12 & 192 & 101 & 116 & 26 \\
\hline & October & 128 & 37 & 36 & $-\overline{51}$ & 104 & 38 & 19 & -61 \\
\hline & November & 82 & -48 & 159 & 47 & 138 & 25 & 83 & -11 \\
\hline & December & 107 & -49 & 98 & $-\mathbf{5 1}$ & 185 & 41 & 83 & -26 \\
\hline \multirow[t]{12}{*}{1997} & January & 101 & $-\mathbf{3 3}$ & 162 & 25 & 166 & 13 & 133 & 14 \\
\hline & February & 221 & 95 & 79 & -42 & 151 & 9 & 203 & 89 \\
\hline & March & 80 & -68 & 99 & $-\mathbf{5 5}$ & 96 & -68 & 38 & -101 \\
\hline & April & 201 & 88 & 110 & -35 & 98 & -36 & 136 & 31 \\
\hline & May & 176 & 44 & 205 & 79 & 298 & 192 & 66 & -40 \\
\hline & June & 100 & 0 & 94 & $-\mathbf{3}$ & 259 & 169 & 137 & 35 \\
\hline & July & 116 & 19 & 74 & -45 & 111 & -16 & 169 & 43 \\
\hline & August & 41 & -47 & 67 & -29 & 92 & 5 & 47 & $-\mathbf{5 0}$ \\
\hline & September & 71 & 8 & 78 & -16 & 37 & -54 & 176 & 86 \\
\hline & October & 147 & 56 & 97 & 10 & 88 & 22 & 196 & 116 \\
\hline & November & 80 & -50 & 55 & -57 & 98 & -15 & 100 & 6 \\
\hline & December & 196 & 40 & 113 & -36 & 136 & -8 & 159 & 50 \\
\hline 1998 & January & 290 & 156 & 142 & 5 & 252 & 99 & 165 & 46 \\
\hline
\end{tabular}


Table 3. Stolon length of white clover grown at four locations and stocked continuously with cattle (mean of eight entries).

\begin{tabular}{|c|c|c|c|c|c|c|}
\hline Year & Month & Winnsboro, LA & Mississippi State, MS & Winfield, AL & Watkinsville, GA & LSD (0.05) \\
\hline & & & & $\mathbf{m} \mathbf{m}^{-2}$ & & \\
\hline \multirow[t]{3}{*}{1996} & April & 112.0 & 129.4 & 80.2 & 89.8 & 25.6 \\
\hline & July & 42.8 & 93.1 & 61.8 & 15.7 & 17.6 \\
\hline & October & 2.5 & 7.3 & 15.6 & 14.4 & 8.1 \\
\hline \multirow[t]{4}{*}{1997} & January & 12.9 & 25.2 & 44.6 & 26.0 & 17.1 \\
\hline & April & 36.8 & 26.2 & 47.2 & 30.6 & 20.7 \\
\hline & July & 22.7 & 50.8 & 68.0 & 41.9 & 20.0 \\
\hline & October & 1.7 & 12.8 & 0.0 & 20.0 & 6.3 \\
\hline 1998 & January & 17.3 & 39.4 & 0.0 & 27.5 & 13.6 \\
\hline
\end{tabular}

by examining results for stolon length. Despite belownormal precipitation in five of the first $6 \mathrm{mo}$ at Mississippi State, MS (Table 2), stolon length of all entries at Mississippi State was greater by July 1996 than stolon length at the other three locations (Table 3). A common trend at all locations was a decline in stolon length to a minimum in October followed by an increase through the winter and spring. However, stolon growth after October 1996 and 1997 never attained the values first measured in April 1996, possibly due to stolon consumption by cattle or death due to stolon-rotting fungi (Pederson and Pratt, 1995; Pratt et al., 1998).

Seasonal trends for stolon branching of the eight white clover entries were similar to those for stolon length. Differences between the ecotypes and cultivars or germplasm did not become readily apparent until after plots had been grazed for a year. With the exception of the Louisiana collection, branching of the ecotypes was greater than that of the cultivars and SRVR in January and April 1997 (Fig. 2). As expected, October 1997 differences among entries were again relatively small, but by January 1998, stolon branching of all ecotypes exceeded that of the cultivars and SRVR (1580 vs. 320 branches $\mathrm{m}^{-2}$ ). Thus, while the environmental conditions of the summer and fall had a similar, adverse effect on all the entries, the ecotypes resumed growth more quickly when conditions moderated during the winter and spring.

The superior stolon growth of the ecotypes compared with the cultivars and SRVR was largely attributed to greater production of new axillary stolon buds and survival of these buds. Because many of the ecotypes had greater stolon length at most sampling dates (Fig. 1), and with the exception of Grasslands Prestige, had shorter stolon internode length, they produced more total stolon nodes (data not shown). Often a greater proportion of the nodes produced by some or all of the ecotypes were elongated (produced a stolon branch; Fig. 3A) or were viable (had the potential to produce a stolon branch; Fig. 3B) compared with the cultivars or SRVR. These differences were particularly evident during the spring and summer. The ability to produce and maintain stolon branches, especially during periods of environmental stress, has been positively associated with the formation of roots at the stolon nodes (Thomas, 1987). Gibson and Cope (1985) also listed strength of rooting at nodes as a desirable trait to incorporate into germplasm. Except in April 1996 and 1997, some or all of the ecotypes had a greater proportion of nodes that were rooted than all of the cultivars or SRVR (Fig. 4). The GA-N collection had a particularly high proportion of nodes rooted compared with the other entries during October

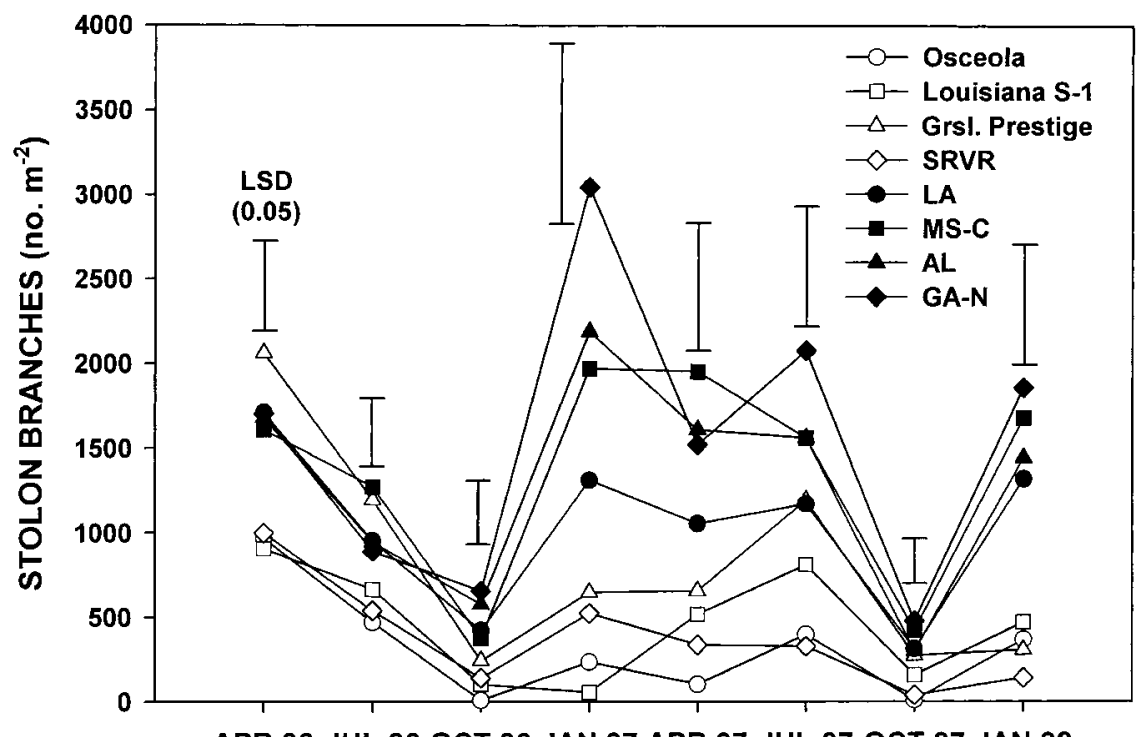

APR 96 JUL 96 OCT 96 JAN 97 APR 97 JUL 97 OCT 97 JAN 98

Fig. 2. Number of stolon branches of three white clover cultivars, one germplasm, and four ecotypes stocked continuously with cattle (mean of four locations). 

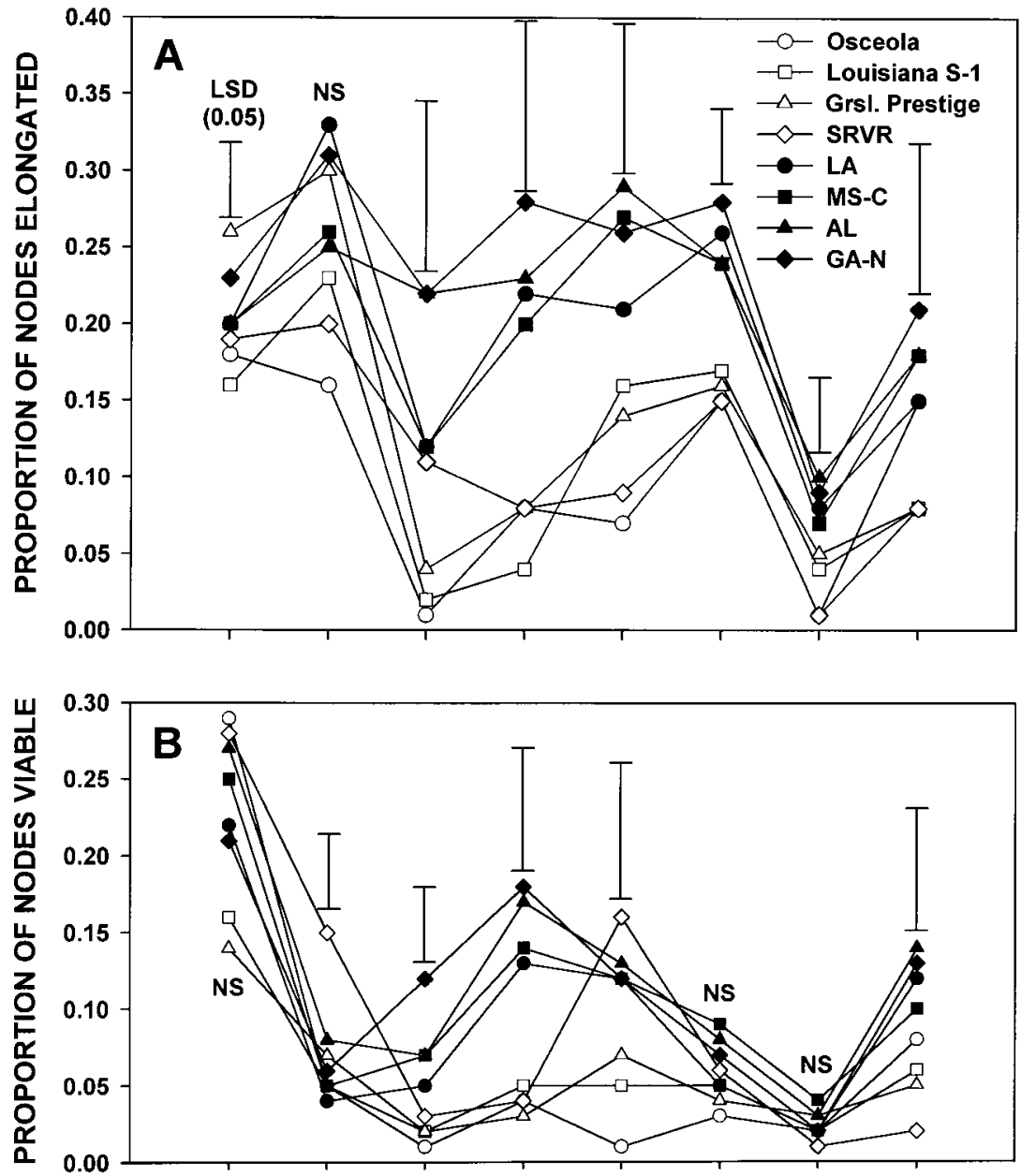

APR 96 JUL 96 OCT 96 JAN 97 APR 97 JUL 97 OCT 97 JAN 98

Fig. 3. Proportion of stolon nodes of three white clover cultivars, one germplasm, and four ecotypes that produced an elongated stolon bud (A) or were capable of producing a viable shoot or root axillary bud $(B)$ when stocked continuously with cattle (mean of four locations).

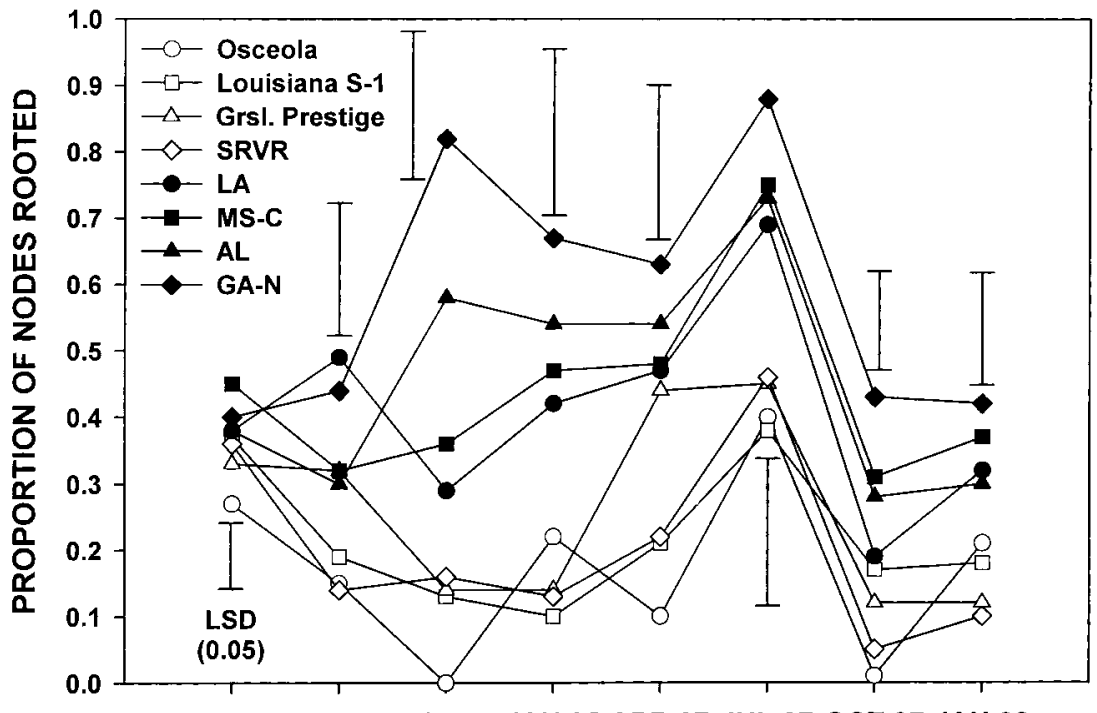

APR 96 JUL 96 OCT 96 JAN 97 APR 97 JUL 97 OCT 97 JAN 98

Fig. 4. Proportion of stolon nodes of three white clover cultivars, one germplasm, and four ecotypes that were rooted when stocked continuously with cattle (mean of four locations). 
1996 and 1997 (0.82 and 0.43, respectively), the low point in growth for all entries.

As stated previously, the production of flowers and seed that results in volunteer reseeding can be an important survival mechanism in white clover (Hollowell, 1966). Under continuous stocking, flower production by the ecotypes in early spring of 1996 and 1997 was consistently greater than that of the other entries at all locations, confirming measurements made by Pederson and Brink (1997). Volunteer seedlings first appeared in plots in January 1997 at the Louisiana location and in April 1997 at the Mississippi, Alabama, and Georgia locations, and were more prevalent in plots of the ecotypes than in plots of other entries (mean of 225 seedlings $\mathrm{m}^{-2} \mathrm{vs} .70 \mathrm{~m}^{-2}$, respectively). Survival of individual seedlings was not documented, but based on observations of the roots and stolons of plants sampled after seedlings appeared, we estimated that $<10 \%$ of the total stolon length was attributable to plants originating from volunteer seedlings. As stolons of the original plants died, the relative contribution of these new plants to the white clover sward would increase.

\section{CONCLUSIONS}

The traits exhibited by the ecotypes collected for this study demonstrate their superior adaptation to the environmental and cultural conditions typically found in pastures across the southeast USA. Greater proportion of stolon nodes that produce branches and become rooted are examples of mechanisms that improve vegetative persistence of ecotypes in heat- and droughtstressed environments subject to frequent defoliation. The ability to produce an abundance of seed under continuous stocking serves as an additional persistence mechanism. Naturalized germplasm thus has great potential to further improve the growth and vegetative persistence of germplasm previously selected for other characters, such as disease resistance (Bouton et al., 1998), or be developed directly into cultivars with superior persistence under close, frequent grazing.

\section{REFERENCES}

Bouton, J.H., C.S. Hoveland, D.R. Woodfield, and J.R. Caradus. 1998 Selection and testing of white clover germplasms derived from naturalized ecotypes. p. 33. In C.R. Grau (ed.) Proc. 15th Trifolium Conference, Madison, WI. 10-12 June 1998. Univ. of Wisconsin, Madison.

Brink, G.E., T.E. Fairbrother, and D.E. Rowe. 1998. Seasonal varia- tion in morphology of continuously stocked white clover. Crop Sci. 38:1224-1228.

Caradus, J.R., A.C. MacKay, D.R. Woodfield, J. van den Bosch, and S. Wewala. 1989. Classification of a world collection of white clover cultivars. Euphytica 42:183-196.

Caradus, J.R., and D.R. Woodfield. 1997. World checklist of white clover varieties II. N. Z.J. Agric. Res. 40:115-206.

Davies, W.E., and N.R. Young. 1967. The characteristics of European, Mediterranean and other populations of white clover (Trifolium repens L.). Euphytica 16:330-340.

Frame, J., and P. Newbould. 1986. Agronomy of white clover. Adv. Agron. 40:1-88.

Forage and Grazing Terminology Committee. 1992. Terminology for grazing lands and grazing animals. J. Prod. Agric. 5:191-201.

Gibson, P.B., O.W. Barnett, G.A. Pederson, M.R. McLaughlin, W.E. Knight, J.D. Miller, W.A. Cope, and S.A. Tolin. 1989. Registration of Southern Regional Virus Resistant white clover germplasm. Crop Sci. 29:241-242.

Gibson, P.B., and W.A. Cope. 1985. White Clover. p. 471-490. In N.L. Taylor (ed.) Clover science and technology. Agron. Monogr. 25. ASA, CSSA, and SSSA, Madison, WI.

Hollowell, E.A. 1966. White clover Trifolium repens L. annual or perennial? p. 184-187. In Proc. Int. Grassl. Congr., 10th. Helsinki, Finland. 7-16 July 1966. Valtioneuvoston Kirjdpaino, Helsinki, Finland.

Knight, W.E., M.R. McLaughlin, C.M. Rincker, G.L. Windham, N.C Edwards, and G.A. Pederson. 1988. Registration of Brown Loam Synthetic No. 2 white clover germplasm. Crop Sci. 28:380.

Newton, P.C.D., and M.J.M. Hay. 1992. Technique for evaluating the potential for growth of shoot and root buds of white clover (Trifolium repens). J. Agric. Sci. (Cambridge) 119:179-183.

Pederson, G.A., and G.E. Brink. 1997. Seed production of pasturecollected white clover populations vs. cultivars. p. 277-279. In M.J. Williams (ed.) Proc. Am. Forage Grassl. Counc. Ft. Worth, TX. 13-15 Apr. 1997. American Forage and Grassl. Council, Georgetown, TX.

Pederson, G.A., and R.G. Pratt. 1995. Differential summer survival of white clover stolons: Germplasm and fungicide effects. Crop Sci. 35:1282-1287.

Pederson, G.A., G.L. Windham, M.M. Ellsbury, M.R. McLaughlin, R.G. Pratt, and G.E. Brink. 1991. White clover yield and persistence as influenced by cypermethrin, benomyl, and root-knot nematode. Crop Sci. 31:1297-1302.

Pratt, R.G., M.R. McLaughlin, G.A. Pederson, and D.E. Rowe. 1998 Pathogenicity of Macrophomina phaseolina to mature plant tissues of alfalfa and white clover. Plant Dis. 82:1033-1038.

Thomas, R.G. 1987. The structure of the mature plant. p. 1-30. In M.J. Baker and W.M. Williams (ed.) White clover. CAB Intl., Wallingford, UK.

Widdup, K.H., J.R. Caradus, J. Green, J.P. Mueller, and C.P. Pennell 1996. White clover ecotype germplasm from the USA for development of New Zealand and overseas cultivars. p. 149-153. In D.R. Woodfield (ed.) White clover: New Zealand's competitive edge. ASNZ Spec. Publ. 11. Agronomy Society of New Zealand, Christchurch, New Zealand.

Williams, W.M. 1987. Genetics and breeding. p. 343-419. In M.J. Baker and W.M. Williams (ed.) White clover. CAB Intl., Wallingford, UK.

Woodfield, D.R., and J.R. Caradus. 1994. Genetic improvement in white clover representing six decades of plant breeding. Crop Sci. 34:1205-1213. 